\title{
COURSE SATISFACTION AND STUDENT ENGAGEMENT IN ONLINE LEARNING AMID COVID-19 PANDEMIC: A STRUCTURAL EQUATION MODEL
}

\author{
Dr. Erick T. BALORAN \\ ORCID: 0000-0001-9978-7672 \\ Department of Teacher Education \\ University of Mindanao - Bansalan College \\ Davao del sur, PHILIPPINES
}

Jenny T. HERNAN

ORCID: 0000-0002-3237-6876

Department of Teacher Education

University of Mindanao - Bansalan College

Davao del sur, PHILIPPINES

Janice S. TAOY

ORCID: 0000-0003-0958-6231

Department of Teacher Education

University of Mindanao - Bansalan College

Davao del sur, PHILIPPINES

Received: 13/11/2020 Accepted: 08/04/2021

\begin{abstract}
The adoption of online learning modality among Higher Education Institutions increased exponentially amid the COVID-19 pandemic. As the universities shifted from onsite learning to online learning, course satisfaction and student engagement became the emerging concern among teachers. This study was designed to determine the significant relationship between course satisfaction and student engagement in online learning during the COVID-19 pandemic in the University of Mindanao - Bansalan College, Philippines. A total of 529 university students responded to the online survey. Results showed students' high level of course satisfaction and engagement with online learning delivery. Students have the same level of satisfaction on online learning delivery quality but have different online learning engagement levels as to year level. Also, this study revealed that online course satisfaction was significantly correlated with online student engagement. Through structural equation modeling, it was further specified that online course satisfaction is significantly related to students' skills engagement, emotion engagement, participation engagement, and performance engagement as constructs of student engagement in online learning. Higher Education Institutions (HEIs) need to improve online learning delivery quality in the new normal setting amid the COVID-19 pandemic and ensure to fill the gap between those students from advantaged and underprivileged backgrounds.
\end{abstract}

Keywords: Course satisfaction, student engagement, online learning, COVD-19 pandemic, Structural Equation Model. 


\section{INTRODUCTION}

The sudden outbreak of COVID-19, a deadly disease, shook the whole world. It was declared a pandemic by the World Health Organisation. This pandemic has caused several schools and colleges to remain closed temporarily. Many places are impacted globally, and there is a fear of missing a semester or even more soon. Onsite instruction has been abandoned by numerous schools, colleges, and universities, and the standard approach to teaching has been modified. Such circumstances cause educational institutions around the world to force teachers to move to an online teaching mode. There was no choice but to switch entirely to online teaching-learning for several academic institutions that were previously unwilling to shift their conventional pedagogical approach (Dhawan, 2020). In China, where the COVID-19 pandemic came from, online education among its universities has been increasingly introduced after the virus outbreak. There has been a change from normal classrooms to e-classrooms overnight, i.e., educators have changed their whole pedagogical approach to meet emerging market dynamics and adjust to changing circumstances. During this challenging era, the question is not whether online teaching-learning strategies will provide quality education; instead, it is how online learning can be embraced in such a big way by academic institutions (Carey, 2020).

Generally, online learning has many opportunities available, but as most academic institutions have moved to this model, this period of crisis will cause online learning to boom. During the COVID-19 pandemic, online learning, remote working, and e-collaboration exploded. Amid this crisis, however, e-learning has some drawbacks because it can hamper contact between the learner and the instructor, i.e., direct communication and lack of human touch. Users may face several technical challenges that hinder and slow down the process of teaching and learning (Favale et al., 2020). Countries like Switzerland, Norway, Austria, United States, Australia, and Indonesia face problems in online education in terms of the significant gap between those students from privileged and disadvantaged backgrounds. While some schools and governments have been providing digital equipment to students in need, many are still concerned that the pandemic will widen the digital divide (Li \& Lalani, 2020).

The COVID-19 crisis has also affected the context of education in the Philippines. Classes were postponed due to lockdown. The majority of universities and colleges have faced virtual learning challenges (Talidong $\&$ Toquero, 2020). Besides, students were unwilling to implement the online-blended learning approach (Baloran, 2020). Nevertheless, despite difficulties, online learning can also bring significant improvements in students ' learning experiences. Students can learn and interact with teachers and other students independently (Singh \& Thurman, 2019). The synchronous learning environment is structured because students attend live lectures, there are real-time interactions between teachers and learners, and instant feedback is possible (Littlefield, 2018). Likewise, synchronous learning can provide many social interaction opportunities (McBrien et al., 2009). Such online platforms are needed amid this deadly virus where video conferencing, discussions with students can be carried out to keep classes organic, internet connections are good, lectures are accessible on mobile phones as well, and not just laptops, the ability to watch already recorded lectures, and immediate student feedback can be obtained, and assignments can be taken (Basilaia et al., 2020).

Previous studies on students' satisfaction towards online learning were conducted even before the COVID-19 pandemic. Singh and Min (2017) studied the level of satisfaction of students with e-learning, and it was found that the majority of students accepted digital learning. Mamattah (2016) also revealed that students were satisfied with online learning compared to face-to-face learning. However, several authors have indicated that students prefer face-to-face teaching over online teaching (Bali \& Liu, 2018; Qureshi et al., 2012). Similarly, during COVID-19, expectations of students about e-learning were explored in the study conducted by Abbasi et al. (2020). During the lockdown case, students didn't choose e-teaching over faceto-face teaching. In their report, it was proposed that the administration and faculty members should take the requisite steps to improve e-teaching during lock-down for better learning.

Higher education institutions consider student satisfaction to be one of the main factors determining their online learning quality, especially with student engagement. Student satisfaction with online learning can be linked to many factors, such as online interactions including student-student, student-instructor, and student-content, and also the quality of course, evaluation, self-efficacy of computer and internet, perceived 
learning and student learning can be influenced by student satisfaction with the learning experience. If students are pleased with their online learning experience, this will decide whether they are more likely to choose to participate in other online courses (Bayrak et al., 2020).

Therefore, student engagement is another critical concern in online learning. The standard of learning has become online learning, and a significant number of students engage in it. The nature of online learning is the continuing growth of students' cognitive level, and students need to engage actively in learning to achieve successful understanding. However, some experiences of students who engage in online learning are not satisfactory because of the lack of contact between teachers and students, and their persistence and effectiveness are also lacking. There are instances where teachers cannot understand the degree of engagement of students, especially the degree of emotional engagement. Therefore, in the online learning environment, it is essential to evaluate and research student engagement, help teachers understand student engagement and intervene in time, help students reflect on their learning actions, and facilitate their profound involvement in the learning process ( $\mathrm{Hu} \& \mathrm{Li}, 2017$; Lisha \& Zhang, 2003). With these preceding contexts, colleges and universities in the Philippines are at the stage of evaluating whether online learning pedagogy amid the COVID-19 pandemic has brought tertiary learners to feel high satisfaction towards online learning and how this influences their learning engagement in terms of developing skills, emotions, participation, and performance. Also, the role of course satisfaction and student engagement in online learning in the context of new normal instruction has received little attention by most researchers to inform policy and practices in the Philippine context. This study's findings will be of significance to higher education institutions (HEIs), particularly in the University of Mindanao management, to be aware of students' course satisfaction and engagement in online learning amid the COVID-19 pandemic. This will help HEIs improve their orientation programs for both teachers and students on online learning modalities and tools and initiate actions in augmenting e-learning resources and online teaching strategies, especially in terms of content delivery and online activities and tasks.

\section{PURPOSE OF THE STUDY}

This study investigated the significant influence of course satisfaction on student engagement in online learning at the University of Mindanao - Bansalan College amid the COVID-19 pandemic. Furthermore, this study aimed to determine the best fit model showing the interrelationships between and among course satisfaction and student engagement domains in online learning.

The study was guided by the following research questions and hypotheses:

The research questions were;

1. What is the level of course satisfaction and student engagement in online learning (in terms of skills, emotion, participation, and performance) amid the COVID-19 pandemic?

2. Is there a significant difference in the level of course satisfaction and student engagement in online learning amid the COVID-19 pandemic when analyzed by gender, age, year level, and course?

3. Is there a significant relationship between course satisfaction and student engagement in online learning amid the COVID-19 pandemic?

4. What model best fits for interpreting structural interrelationships among course satisfaction and student engagement domains in online learning amid the COVID-19 pandemic?

The hypotheses were;

1. There is no significant difference in the level of course satisfaction and student engagement in online learning amid the COVID-19 pandemic when analyzed by gender, age, year level, and course.

2. There is no significant relationship between course satisfaction and student engagement in online learning amid the COVID-19 pandemic.

3. There is no model that best fits for interpreting structural interrelationships among course satisfaction and student engagement domains in online learning amid the COVID-19 pandemic. 


\section{METHOD}

This was a cross-sectional study conducted at the University of Mindanao - Bansalan College, Philippines, from October 3 to 22, 2020, amid the community lockdowns due to the COVID-19 pandemic. The interrelationships among students' course satisfaction and student engagement domains in online learning were determined using the structural equation modeling (SEM) technique.

\section{Study Sample}

A total of 529 university students were the respondents of the study. Students were informed about the purpose of the study, and online consent was obtained. Among the 529 university students who answered the online questionnaire, 296 (55.95\%) were male, 220 (41.59) were male, and 13 (2.46\%) were LGBTQ+ members. The majority of the students belonged to 20 to 25 -years-old (290 or 54.82\%) and was first-year students (220 or $41.59 \%$ ). Also, the majority were taking law enforcement courses (368 or $69.57 \%$ ) (See Table 1).

Table 1. Demographic Description of the Study Sample

\begin{tabular}{|c|c|c|}
\hline Characteristics & Value & \\
\hline \multicolumn{3}{|l|}{ Gender, n (\%) } \\
\hline & Male & $296(55.95)$ \\
\hline & Female & $220(41.59)$ \\
\hline & LGBTQ+ & $13(2.46)$ \\
\hline \multicolumn{3}{|l|}{ Age, n (\%) } \\
\hline & Below 19 y/o & $209(39.51)$ \\
\hline & $20-25 \mathrm{y} / \mathrm{o}$ & $290(54.82)$ \\
\hline & $26-30 y / o$ & $27(5.10)$ \\
\hline & 31 y/o and above & $3(0.57)$ \\
\hline \multicolumn{3}{|l|}{ Year Level, n (\%) } \\
\hline & First Year & $220(41.59)$ \\
\hline & Second Year & $144(27.22)$ \\
\hline & Third Year & $127(24.01)$ \\
\hline & Fourth Year & $38(7.18)$ \\
\hline \multicolumn{3}{|l|}{ Course, n (\%) } \\
\hline & Law Enforcement & $368(69.57)$ \\
\hline & Business Administration & $101(19.09)$ \\
\hline & Education & $33(6.24)$ \\
\hline & Management Accounting & $27(5.10)$ \\
\hline
\end{tabular}

\section{Data Collection and Analysis}

The course satisfaction of students in online learning was assessed using a 10-item questionnaire adapted from the study of Bayrak et al. (2020) on the Development of Online Course Satisfaction Scale. The student engagement in online learning was also assessed using a 19-item questionnaire adapted from the study of Dixson (2015) on the Measuring Student Engagement in the Online Course: The Online Student Engagement Scale (OSE). Demographic information such as gender, age, year level, and course were also 
obtained. Students were asked to respond to the questionnaire items on a five-point Likert scale. Student respondents answered the online survey developed through Google forms with an appended consent form. The survey link was sent to the student respondents via social media. The study involved only those students who had access to the internet and enrolled in online learning modalities. In analyzing data, Mean was used to assess the level of course satisfaction and student engagement, and Analysis of Variance (ANOVA) was used to test the significant difference in the level of course satisfaction and student engagement in online learning when analyzed by gender, age, year level, and course. Pearson $r$ was used to determine the significant relationship between the variables. To verify the normal distribution of the given data, the normality test (Shapiro-Wilk Test) was used. To approximate the structural model, path analysis was further incorporated into the SEM analysis. To determine the fitness of the hypothesized model, several measures were used. Finally, to better approach the direct relations between the measured variables, path analysis was used (Hair et al., 2006).

\section{The Scale}

The test items' overall reliability was assessed by calculating Cronbach's alpha (0.897), which indicates significant internal consistency. A five point likert scale was used for measuring the levels of course satisfaction and student engagement. The following range of means with its descriptions was used: $1.00-1.79$ (Very Low); 1.80 - 2.59 (Low); 2.60 - 3.39 (Moderate); 3.40 - 4.19 (High); 4.20 - 5.00 (Very High). The corresponding interpretation for each range starts from never to rarely, sometimes, oftentimes, and always manifested for every item in the questionnaire.

\section{RESULTS AND DISCUSSION}

\section{Course Satisfaction and Student Engagement in Online Learning}

The study's first objective was to investigate the level of course satisfaction and the level of student engagement in online learning in terms of skills, emotion, participation, and performance amid the COVID-19 pandemic in the University of Mindanao - Bansalan College, Philippines. As seen in Table 2, students' level of course satisfaction in online learning amid the COVID-19 pandemic is 'high' ( $M=3.64 ; S D=0.78)$. Data implies that in the first term of the semester, the university students are highly satisfied with how teachers communicate and provide support to students in gaining access to different online materials for course learning. Students are contented with how learning units are sequenced, scheduled, and presented using the Learning Management System (LMS) and other forms of online modalities. Teachers present lesson content online clearly and understandably. Also, students display a high level of satisfaction in terms of the speed and easy utility of the LMS and other online teaching platforms. They also see their teachers being enthusiastic in giving feedback to their performances during the online learning mode. Hence, students are highly satisfied that their learning needs are met in the online learning environment amid the COVID-19 pandemic.

Table 2. Levels of Course Satisfaction and Student Engagement in Online Learning

\begin{tabular}{|c|c|c|c|c|c|c|}
\hline & \multirow{2}{*}{$\begin{array}{c}\text { Course } \\
\text { Satisfaction } \\
\text { (Crs) }\end{array}$} & \multicolumn{4}{|c|}{ Student Engagement (SE) Domains } & \multirow{2}{*}{$\begin{array}{c}\text { Overall } \\
\text { SE }\end{array}$} \\
\hline & & $\begin{array}{l}\text { Skills } \\
\text { (Skl) }\end{array}$ & $\begin{array}{c}\text { Emotion } \\
\text { (Emt) }\end{array}$ & $\begin{array}{c}\text { Participation } \\
\text { (Prt) }\end{array}$ & $\begin{array}{c}\text { Performance } \\
\text { (Prf) }\end{array}$ & \\
\hline Valid & 529 & 529 & 529 & 529 & 529 & 529 \\
\hline Missing & 0 & 0 & 0 & 0 & 0 & 0 \\
\hline Mean & 3.64 & 4.05 & 4.14 & 3.86 & 3.87 & 3.98 \\
\hline Std. Deviation & 0.78 & 0.70 & 0.72 & 0.77 & 0.79 & 0.65 \\
\hline Descriptive Level & High & High & High & High & High & High \\
\hline
\end{tabular}


The result is consistent with the findings of various researches which stated that it is possible to achieve student satisfaction in online learning by positive online teacher learning activities (An et al., 2008; Chen, 2014; Lister, 2014; Tibi, 2015). In online learning, timely and explanatory teacher feedback is also relevant (Britto \& Rush, 2013; Sebastianelli et al., 2015; Wallace, 2003); and consistent teacher and virtual student contact (Lister, 2014; Roper, 2007; Uusiautti et al., 2017). Therefore, as Gil (2008) stated, the four most influential categories of online learning satisfaction are management, functionality, teaching, and interaction. In combination, the continuous expansion of online resources is vital for the university to make students' online course learning easy and efficient, taking into account the high level of student satisfaction in online learning. This supports the argument of different authors (Parahoo et al., 2016; Yukselturk \& Yildirim, 2008), which indicated that online learning satisfaction of students remains one of the most critical measures of the quality of online learning experiences and is one of the essential elements in assessing the quality of online learning for higher education institutions.

In terms of the overall level of student engagement in online learning amid the COVID-19 pandemic, the data shows that students have a 'high' level of engagement in online learning $(M=3.98 ; S D=0.65)$. Its domains got mean scores, to wit: 4.05 ( $\mathrm{SD}=0.70)$ or "high" for skills, 4.14 ( $\mathrm{SD}=0.72)$ or 'high' for emotion, $3.86(\mathrm{SD}=0.77)$ or 'high' for participation and $3.87(\mathrm{SD}=0.79)$ or 'high' for performance. Data implies that in the first term of the semester, the university students have a level of engagement in online learning who keep up with readings and put forth efforts on tasks. They also make the course interesting and consequently apply it to their own lives. Further, students have strong interaction and active participation engagement in online discussions. As to online course performance, students are doing well on tests and get good grades. The result of the study is consistent with the statement by Handelsman et al. (2005), which stressed that students devote time and energy to online learning in terms of skills engagement, emotional engagement, participation engagement, and performance engagement, all of which represent students' high learning engagement. Besides, Dixson (2015) clarified that students could use time and resources to acquire materials and skills through online learning, showing that learning, communicating with others online positively, and being at least somewhat emotionally involved with their learning. Students with a degree of dedication to online learning have constructive attitudes, emotions, and actions and virtual contact with others. They feel good about their learning and their connections with the content, the teacher, and other students in terms of skills, participation, performance, and emotion.

\section{Significant Difference in the Level of Course Satisfaction and Student Engagement in Online Learning when Analyzed by Gender, Age, Year Level, and Course}

The second objective of the study was to determine the significant difference in the level of course satisfaction and student engagement in online learning amid the COVID-19 pandemic in the University of Mindanao Bansalan College, Philippines. Students' course satisfaction and engagement in online learning were compared in terms of gender, age, year level, and course (see Table 3). The analysis of the data indicates that there was no statistically significant difference in the level of course satisfaction of students from different groups since ANOVA results show p-values of 0.728 (gender), 0.180 (age), 0.428 (year level), and 0.149 (course). Hence, the null hypothesis was accepted. This presupposes that students at the University of Mindanao - Bansalan College have the same course satisfaction level in online learning. They have similar perceptions of the quality of online learning delivery. They experience comparable satisfaction levels in meeting their needs in the online learning environment amid the COVID-19 pandemic, especially in terms of content delivery and teachers' communication and feedback. According to a study of various authors (Anifowoshe et al., 2020; Demuyakor, 2020; Owusu-Fordjour et al., 2020), amid this COVID-19 pandemic, students' feel satisfied with online learning if while studying online from home, they will have the opportunity to ask questions about the lesson contents and expect a timely response from their online teachers. Hence, in the context of 
academic work, teachers' timely feedback is essential. On the other hand, the data shows that there was no statistically significant difference in the level of student engagement in online learning from different groups since ANOVA results show p-values of 0.751 (gender), 0.874 (age), and 0.478 (course), except for year level ( $\mathrm{p}$-value $=0.006$ or 'significant'). Results on post hoc comparisons show that the level of engagement in the second year students' online learning is significantly different from the third-year students ( $\mathrm{p}$-value $=0.003$ or 'significant'). This implies that these students from two different year level groups have varying engagement in online learning and online connections with the content, the teacher, and other students in terms of skills, participation, performance, and emotion.

Table 3. Test of Difference in the Level of Course Satisfaction and Student Engagement in Online Learning when analyzed by Gender, Age, Year Level and Course

\begin{tabular}{lccccccc}
\hline & Cases & $\begin{array}{c}\text { Sum of } \\
\text { Squares }\end{array}$ & df & $\begin{array}{c}\text { Mean } \\
\text { Square }\end{array}$ & F & p & Description \\
\hline \multirow{2}{*}{ Course } & Gender & 0.388 & 2.000 & 0.194 & 0.318 & 0.728 & NS \\
Satisfaction & Age & 2.983 & 3.000 & 0.994 & 1.637 & 0.180 & NS \\
& Year Level & 1.694 & 3.000 & 0.565 & 0.925 & 0.428 & NS \\
Student Engage- & Course & 3.253 & 3.000 & 1.084 & 1.786 & 0.149 & NS \\
ment & Gender & 0.242 & 2.000 & 0.121 & 0.287 & 0.751 & NS \\
& Age & 0.295 & 3.000 & 0.098 & 0.232 & 0.874 & NS \\
& Year Level & 5.169 & 3.000 & 1.723 & 4.167 & 0.006 & S \\
\hline
\end{tabular}

Statistical significance at $p<0.001$

$N S=$ Not Significant; $S=$ Significant

Post Hoc Comparisons - Year Level (Second Year vs. Third Year); $p=0.003$

\section{Relationship between Course Satisfaction and Student Engagement in Online Learning}

This study's third objective was to determine the significant relationship between course satisfaction and student engagement in online learning amid the COVID-19 pandemic in the University of Mindanao - Bansalan College, Philippines. The results of the normality tests indicate the normal distribution of the data $(<.001)$. Pearson correlation coefficient analysis was performed to explain the relationships between the Crs and SE constructs (Skl, Emt, Prt, and Prf). The results from Table 4 show that in general, when the online course satisfaction was correlated with the online student engagement, it gained a correlation value of 0.336 with p-value of $<.001$ or 'significant.' When the course satisfaction was correlated with the student engagement domains, results revealed the correlation values and p-values, to wit: skills ( $\mathrm{r}$-value $=0.333$; $\mathrm{p}$-value of $<.001$ or 'significant'); emotion $(\mathrm{r}$-value $=0.322 ; \mathrm{p}$-value of < .001 or 'significant'); participation ( $\mathrm{r}$-value $=0.295$; $\mathrm{p}$-value of $<.001$ or 'significant'); and performance ( $\mathrm{r}$-value $=0.229 ; \mathrm{p}$-value of $<.001$ or 'significant'). This rejects the null hypothesis. This presupposes that online course satisfaction is a significant factor that influences student engagement in online learning. Students who are satisfied with online activities, tasks, and communications also have a high level of online learning engagement and have augmented online networks and potentials with others in terms of skills, participation, performance, and emotion. As stipulated by Bayrak et al. (2020), universities need to consider student satisfaction in online learning. It is one factor for determining the quality of online pedagogy and affects students' learning engagement online. Students with a high level of online pedagogy satisfaction are more likely to continue to pursue online courses. 
Table 4. Pearson Correlation Coefficient Analysis on the Relationship between Course Satisfaction and Student Engagement in Online Learning

\begin{tabular}{llrrrrrr}
\hline \multicolumn{1}{c}{ Variable } & & Crs & SE & Skl & Emt & Prt & Prf \\
\hline 1. Course Satisfaction & Pearson's r & - & & & & & \\
& p-value & - & & & & \\
2. Student Engagement & Pearson's r & 0.336 & - & & & \\
3. Skills & p-value & $<.001$ & - & & & \\
& Pearson's r & 0.333 & 0.887 & - & & \\
4. Emotion & p-value & $<.001$ & $<.001$ & - & & \\
& Pearson's r & 0.322 & 0.877 & 0.796 & - & \\
5. Participation & p-value & $<.001$ & $<.001$ & $<.001$ & - & & \\
& Pearson's r & 0.295 & 0.885 & 0.686 & 0.702 & - & \\
6. Performance & p-value & $<.001$ & $<.001$ & $<.001$ & $<.001$ & - & \\
& Pearson's r & 0.229 & 0.838 & 0.632 & 0.577 & 0.686 & - \\
& p-value & $<.001$ & $<.001$ & $<.001$ & $<.001$ & $<.001$ & - \\
\hline
\end{tabular}

\section{Interrelationships among Course Satisfaction (Crs), Skills Engagement (Skl), Emotion} Engagement (Emt), Participation Engagement (Prt), and Performance Engagement (Prf)

The technique of SEM was applied to test the hypothesized model that specifies the relations among course satisfaction (Crs), skills engagement (Skl), emotion engagement (Emt), participation engagement (Prt), and performance engagement (Prf). First, the evaluation of model-to data-fit indices showed that the proposed model well explained the data. Among the fit indices, the values of Chi-square $=9.182 \mathrm{e}-14$, degree of freedom $=2, \mathrm{p}<.001, \mathrm{GFI}=0.95, \mathrm{CFI}=0.96, \mathrm{NFI}=0.96, \mathrm{SRMR}=0.031, \mathrm{RMSEA}=<0.001$ indicated a good model fit (Hair et al., 2006; Hu \& Bentler, 1999). These fit statistics suggested that the hypothesized model was appropriate for interpreting the structural relationships among Crs, Skl, Emt, Prt, and Prf.

Path analysis was then employed to assess the direct relationships among each variable of the structural model. Figure 1 illustrates the parameter estimates for the structural model. As shown in the figure, 'Course Satisfaction' in online learning was a significant and positive factor predicting students' skills engagement $(\beta=0.33, \mathrm{p}<$ $.001)$, emotion engagement $(\beta$ $=0.32, \mathrm{p}<.001)$, participation engagement $(\beta=0.29, \mathrm{p}$ $<.001)$, and performance engagement $(\beta=0.23, \mathrm{p}<$ $.001)$. Taken together, course satisfaction played a direct role in student engagement aspects in terms of skills, emotion, participation, and performance in online learning amid the COVID-19 pandemic.

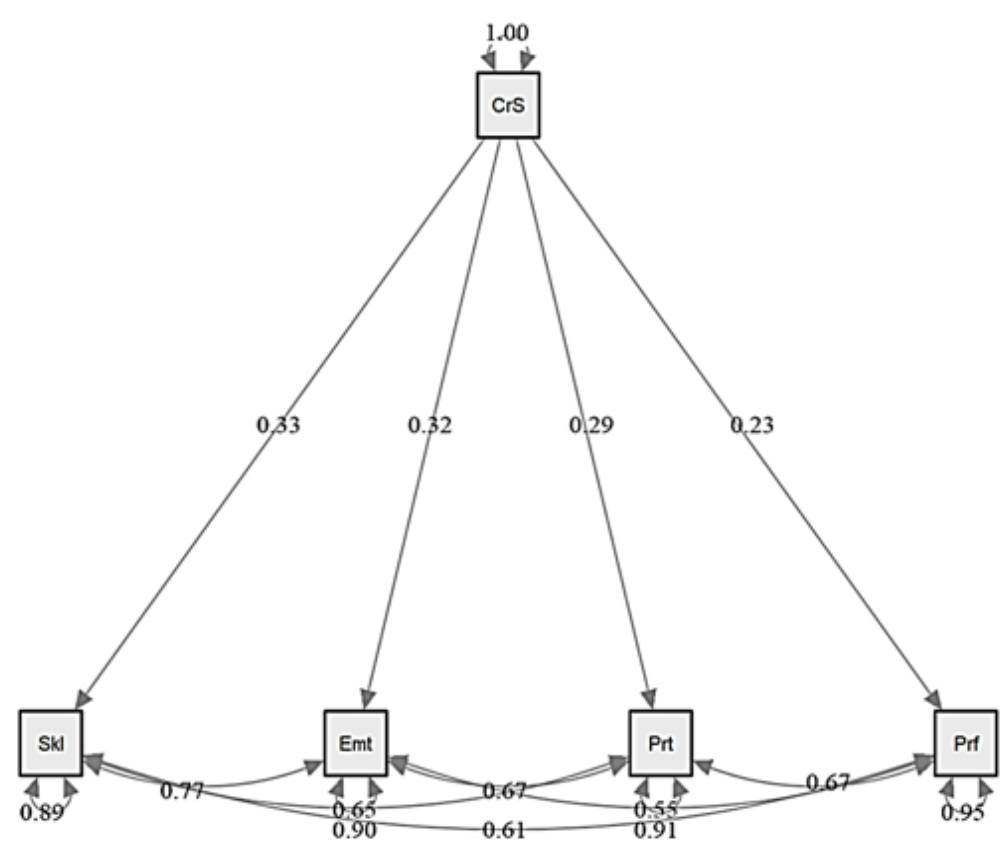

Figure 1. The Final Model of the Structural Relations among Crs, Skl, Emt, Prt, and Prf 


\section{CONCLUSION AND RECOMMENDATIONS}

The adoption of online learning modality among Higher Education Institutions increased exponentially amid the COVID-19 pandemic. As the universities shifted from onsite learning to online learning, course satisfaction and student engagement became the emerging concern among teachers. As the academic institutions adjust to the new normal pedagogical setting, it is essential to assess online learning delivery quality by determining students' course satisfaction and, consequently, ascertaining how this influences their online learning engagement. In this study, the findings revealed that students are highly satisfied with online learning delivery. Students are highly satisfied that their learning needs are met in the online learning environment amid the COVID-19 pandemic, especially with how teachers establish online communication and provide constant feedback on students' performance online. Online learning contents are also delivered effectively and intelligibly by teachers. The high level of student engagement in online learning was also recorded in this study. Students allocate time and energy in online learning through their high level of skills, positive attitude, interaction, participation, and interactions online. Data also revealed that the students have the same level of satisfaction on the quality of online learning delivery, but have different online learning engagement levels as to year level particularly the second year and third year students. One significant finding of this study was that online course satisfaction was correlated with online student engagement. Students who are satisfied with the learning opportunities provided by teachers online are more likely to be engaged online in terms of course skills, participation, performance, and emotion. Further, through structural equation modeling, it was further specified that online course satisfaction is significantly related with students' skills engagement, emotion engagement, participation engagement, and performance engagement constructs of student engagement in online learning.

Based on the study's findings and conclusion, we recommend that the Higher Education Institutions (HEIs) may improve online learning delivery quality in the new normal setting amid the COVID-19 pandemic. With the rapid transfer from onsite to online learning, it is recommended for teachers to provide learning materials online that help augment student online learning engagement. Teachers may organize course contents and employ online teaching strategies to help students feel emotionally, cognitively, and socially engaged throughout the online learning process. Further, teachers may strengthen communication and feedback practices online. The school administrators may invest time in continuous assessment on the quality delivery of online learning, course satisfaction, and learning engagement and use these assessment results for policymaking and academic management decisions. With the new mode of teaching delivery, adequate and appropriate online resources and materials may be provided to students to assist their online learning needs and consequently develop their knowledge, skills, and performance, and positive attitudes towards learning. Likewise, universities may invest in effective, efficient and easy-to-access Learning Management System (LMS) and other online learning tools. Hence, HEIs may consider the idea that online learning's effectiveness amid this COVID-19 pandemic depends on the satisfactory learning materials and resources, teachers' facilitation and engagement in the online environment, and meaningful teacher-student or studentstudent interactions. 


\section{BIODATA and CONTACT ADDRESSES of AUTHORS}

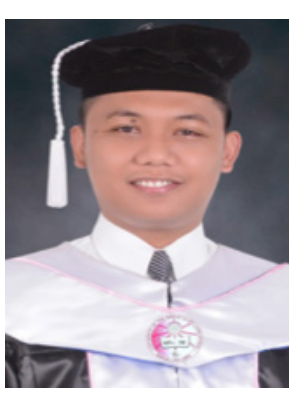

Dr. Erick T. BALORAN is an Associate Professor and Dean of College of the University of Mindanao - Bansalan College and working as the Department of Teacher Education program coordinator. Dr. Baloran is also currently the Research Coordinator of the college. He holds a bachelor's degree in Secondary Education major in English and a master's degree in Education major in Language Teaching. He earned a Doctor of Philosophy in Education major in Applied Linguistics at the University of the Immaculate Conception, Davao City, Philippines. His research areas include issues concerning distance learning, linguistics and language teaching, educational leadership and inclusive education, cases on crime, business, and health sciences. He has various research articles published in international refereed journals covering topics such as the impact of the COVID-19 pandemic in education.

\section{Erick T. BALORAN}

Department of Teacher Education

Adress: University of Mindanao - Bansalan College,

8005, Bansalan, Davao del Sur, Philippines

Phone: +63 (910) 3034340

E-mail: erickbaloran.research@gmail.com

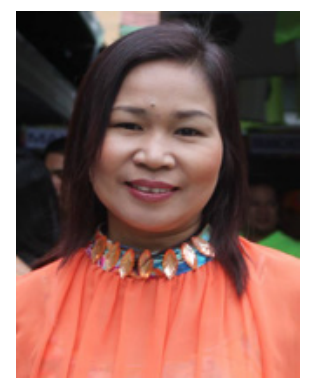

Jenny T. HERNAN is an Associate Professor and School Director of the University of Mindanao - Bansalan College. She holds a bachelor's degree in Elementary Education major in English and a master's degree in Education major in Administration and Supervision. She is presently completing her dissertation for her Ph.D. Degree in Applied Linguistics at the Professional Schools, University of Mindanao, Davao City, Philippines. Her research interests include social science research, educational management and supervision, English language teaching, linguistics, and the impact of COVID-19 pandemic on the academe.

\section{Jenny T. HERNAN}

Department of Teacher Education

Adress: University of Mindanao - Bansalan College,

8005, Bansalan, Davao del Sur, Philippines

Phone: +63 (933) 8205691

E-mail: jennyhernan@umindanao.edu.ph

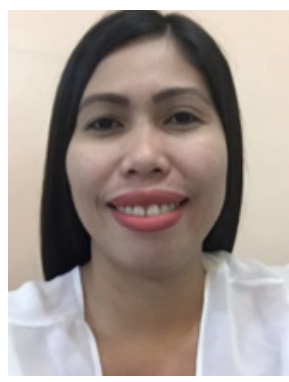

Janice S. TAOY is an Associate Professor of the University of Mindanao - Bansalan College. She is currently the Quality Manager Assistant Manager of the college and holds a bachelor's degree in Secondary Education major in English. She is presently completing her Master's Degree in Education thesis in Teaching English at the Professional Schools, University of Mindanao, Davao City, Philippines. Her research interests include English language teaching and the school's total quality management system.

Janice S. TAOY

Department of Teacher Education

Adress: University of Mindanao - Bansalan College,

8005, Bansalan, Davao del Sur, Philippines

Phone: +63 (909) 0598183

E-mail: janicetaoy.research@gmail.com 


\section{REFERENCES}

Abbasi, S., Tahera, A., Ayoob, T., \& Malik, S. (2020). Perceptions of students regarding e-learning during COVID-19 at a private medical college. Retrieved from https://www.ncbi.nlm.nih.gov/pmcl articles/PMC7306963/pdf/PJMS-36-S57.pdf.

An, H., Kim, S., \& Kim, B. (2008). Teacher perspectives on online collaborative learning: Factors perceived as facilitating and impeding successful online group work. Contemporary Issues in Technology and Teacher Education, 8(1), 65-83.

Anifowoshe, O., Aborode, A.T., Ayodele, T.I., Iretiayo, A.R., \& David, O.O. (2020). Impact of COVID-19 on Education in Sub-Saharan Africa. Preprints, 2020070027.

Baloran, E.T. (2020). Knowledge, attitudes, anxiety, and coping strategies of students during COVID-19 pandemic. Journal of Loss and Trauma, 25(8), 635-642, DOI: 10.1080/15325024.2020.1769300.

Bali, S., \& Liu. M.C. (2018). Students' perceptions toward online learning and face-to-face learning courses. J Physics, 1108:012094. doi :10.1088/1742-6596/1108/1/012094.

Basilaia, G. , Dgebuadze, M., Kantaria, M., \& Chokhonelidze, G. (2020). Replacing the classic learning form at universities as an immediate response to the COVID-19 virus infection in Georgia. International Journal for Research in Applied Science \& Engineering Technology, 8(3).

Bayrak, F., Tibi, M., \& Altun, A. (2020). Development of online course satisfaction scale. Turkish Online Journal of Distance Education-TOJDE, 21(4), 110- 123.

Britto, M., \& Rush, S. (2013). Developing and implementing comprehensive student support services for online students. Journal of Asynchronous Learning Networks, 17, 29-42.

Carey, K. (2020, March 13). Everybody ready for the big migration to online college? Actually, no. Retrieved from https://www.nytimes.com/2020/03/13/upshot/coronavirus-online-college-classes-unprepared. html.

Chen, S. J. (2014). Instructional design strategies for intensive online courses: An objectivist-constructivist blended approach. Journal of Interactive Online Learning, 13(1), 72-86.

Demuyakor, J. (2020). Coronavirus (COVID-19) and online learning in higher institutions of education: A survey of the perceptions of Ghanaian international students in China. Online J. Commun. Media Technol., 10, e202018.

Dhawan, S. (2020). Online learning: A panacea in the time of COVID-19 crisis. Journal of Educational Technology Systems, 49(1) 5-22.

Dixson, M. (2015). Measuring Student Engagement in the Online Course: The Online Student Engagement Scale (OSE). Online Learning, 19(4).

Favale, T., Soro, F., Trevisan, M., Drago, I., \& Mellia, M. (2020). Campus traffic and eLearning during COVID-19 pandemic. Computer Networks, 176, 107290.

Gil, H. (2008). The challenge of the transition from online delivery to online teaching and learning. In K. McFerrin, R. Weber, R. Carlsen, D. A. Williset. (Eds.), Proceedings of Society for Information Technology and Teacher Education International Conference. Chesapeake, VA: AACE, 2589-2594.

Hair, J. F., Black, W. C., Babin, B. J., Anderson, R. E., \& Tatham, R. L. (2006). Multivariate data analysis (Gth ed.). New York, NY: Prentice Hall.

Handelsman, M. M., Briggs, W. L., Sullivan, N., \& Towler, A. (2005). A measure of college student course engagement. The Journal of Educational Research, 93(3), 184-191.

Hu, L.T., \& Bentler, M. P. (1999). Cutoff criteria in fit indexes in covariance structure analysis: Conventional criteria versus new alternatives. Structural Equation Modeling: A Multidisciplinary Journal, 6(1), $1-55$.

Hu, M., \& Li, H. (2017). Student engagement in online learning: A review. International Symposium on Educational Technology (ISET), Hong Kong, 2017, pp. 39-43, doi: 10.1109/ISET.2017.17. 
Li, C., \& Lalani, F. (2020, April 29). The COVID-19 pandemic has changed education forever. This is how. Retrieved from https://www.weforum.org/agenda/2020/04/coronavirus-education-globalcovid19-online-digital-learning/.

Lisha, L., \& Zhang, Q. (2003). The types and characteristics of online learning. Education Science, 1, 49-52.

Lister, M. (2014). Trends in the design of e-learning and online learning. Journal of Online Learning and Teaching, 10(4), 671-680.

Littlefield, J. (2018). The difference between synchronous and asynchronous distance learning. Retrieved from https://www.thoughtco.com/synchronous-distance-learning-asynchronous-distancelearning-1097959.

Mamattah, R.S. (2016). Students' perceptions of e-Learning. Retrieved from https://www.diva-portal.org/ smash/get/diva2:925978/FULLTEXT01.pdf.

McBrien, J. L., Cheng, R., \& Jones, P. (2009). Virtual spaces: Employing a synchronous online classroom to facilitate student engagement in online learning. The International Review of Research in Open and Distributed Learning, 10(3), 1-17.

Owusu-Fordjour, C., Koomson, C.K., \& Hanson, D. (2020). The impact of COVID-19 on learning-The perspective of the Ghanaian student. Eur. J. Educ. Stud., 7, 1-14.

Parahoo, S. K., Santally, M. I., Rajabalee, Y., \& Harvey, H. L. (2016). Designing a predictive model of student satisfaction in online learning. Journal of Marketing for Higher Education, 26(1), 1-19. Doi: https://doi.org/10.1080/08841241.2015.1083511

Qureshi, I.A., Ilyas, K., Yasmin, R., \& Whitty, M. (2012). Challenges of implementing e-learning in a Pakistani university. Know Manag E-Learn, 4 (3). doi: 10.34105/j.kmel.2012.04.025.

Roper, A. R. (2007). How students develop online learning skills. Educause Quarterly, 30(1), 62-65.

Sebastianelli, R., Swift, C., \& Tamimi, N. (2015). Factors affecting perceived learning, satisfaction, and quality in the online MBA: A structural equation modeling approach. Journal of Education for Business, 90(6), 296-305. Doi: https://doi.org/10.1080/08832323.2015.1038979.

Singh, A., \& Min, A.K. (2017). Digital lectures for learning gross anatomy: a study of their efficacy. Korean JMed Educ., 29, 27-32. doi: 10.3946/kjme.2017.50.

Singh, V., \& Thurman, A. (2019). How many ways can we define online learning? A systematic literature review of definitions of online learning (1988-2018). American Journal of Distance Education, 33(4), 289-306.

Talidong, K. J. B., \& Toquero, C. M. D. (2020). Philippine teachers' practices to deal with anxiety amid COVID-19. Journal of Loss and Trauma. Advance online publication. https://doi.org/10.1080/15 325024.2020.1759225.

Tibi, M. H. (2015). Improving collaborative skills by computer science students through structured discussion forums. Journal of Technologies in Education, 10 (3-4), 27-41. doi:10.24059/olj.v22i1.995.

Uusiautti, S., Maatta, K., \& Leskisenoja, E. (2017). Succeeding Alone and Together-University Students' Perceptions of Caring Online Teaching. Journal of Studies in Education, 7(2), 48-66. doi: https:// doi.org/10.5296/jse.v7i2.11162

Wallace, R. M. (2003). Online learning in higher education: A review of research on interactions among teachers and students. Education, Communication, and Information, 3(2), 241-280. doi: https:// doi.org/10.1080/14636310303143.

Yukselturk, E., \& Yildirim, Z. (2008). Investigation of interaction, online support, course structure and flexibility as the contributing factors to students' satisfaction in an online certificate program. Educational Technology \& Society, 11(4), 51-65. 